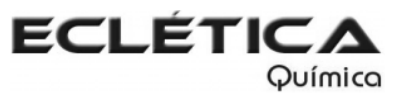

www.scielo.br/eq

Volume 31, número 2, 2006

\title{
Kinetic evaluation of the dehydration of Yb(III) Lu(III) and Y(III) 4-chlorobenzylidenepyruvate by thermogravimetry (TG)
}

\author{
N. S. Fernandes ${ }^{1 *}, S$. A. Araujo ${ }^{1}$, M. Ionashiro ${ }^{2}$ \\ ${ }^{1}$ Universidade Federal do Rio Grande do Norte - UFRN, Departamento de Química, CP 1662, 59078-970, Natal, RN, Brazil \\ ${ }^{2}$ Instituto de Química, Universidade Estadual Paulista, CP 355, 14801-970, Araraquara, SP, Brazil \\ *Author for correspondence: E-mail: nedja@ufrnet.br
}

\begin{abstract}
The dehydration kinetic of $\mathrm{Yb}, \mathrm{Lu}$ and $\mathrm{Y}$ 4-chlorobenzylidenepyruvate was studied by using thermogravimetry and the kinetics parameters obtained by Flynn and Wall method suggest that the dehydration step follows a first order mechanism. The activation energies calculated were 103.6, 96.6 and $97.2 \mathrm{~kJ} / \mathrm{mol}$ and the lifetime considering the temperature of 31 and $101{ }^{\circ} \mathrm{C}$ for the dehydration of these compounds were 23,26, 31 minutes and 0.6, 1.3 and 1.4 seconds, respectively. The results have similar values and suggest that the water is attached in the same way.
\end{abstract}

Keywords: kinetic; thermogravimetry; lanthanides; thermal decomposition.

\section{Introduction}

Kinetic methods used to determine the activation energy, by using integral dynamic curves from TG ones at multiple heating rate has been proposed by Ozawa [1] and for Flynn and Wall [2]. Several studies have been carried out for determination of kinetic parameters as activation energy, pre-exponential factor and lifetime of several materials reactions as catalysts, polymers, organics and inorganics compounds $[3,4,5,6]$.

The main of the present article is to evaluate the kinetic dehydration step for itterbium, lutetium and yttrium 4-clorobenzylidenepyruvates using a software developed by Blaine [7] present in the Thermal Analysis System SDT 2960 simultaneous from TA Instruments based on the kinetic model of Flynn and Wall [2].

\section{Experimental}

The solid-state compounds of trivalent ytterbium, lutetium and yttrium with 4-Chlorobenzylidenepyruvate (4-Cl-BP) were prepared by mixing solutions of the corresponding lanthanide and yttrium chlorides with aqueous solution of the ligand until total precipitation of the metal ion. This procedure was utilized in the preparation of the other trivalent lanthanide pyruvates [8,9]. The precipitates obtained were washed until total elimination of chloride ions, filtered and dried in Whatman № 42 filter papers, and stored in a desiccator over anhydrous calcium chloride.

The TG curves were obtained in a simultaneous system TG/DTA SDT 2960 from TA Instruments using different heating rate $(2,5 ; 5,0$ and $\left.10,0^{\circ} \mathrm{C} \mathrm{min}^{-1}\right)$, dynamic atmosphere of synthetic air with flow of $100 \mathrm{~mL} \mathrm{~min}^{-1}$, alumina crucible and 
samples weighting about $7 \mathrm{mg}$. For the kinetic evaluation of the dehydration of the compounds was considerated the following of conversions percentage: 10, 20, 30, 40, 50, 60 and $70 \%$.

\section{Results and discussion}

TG and DTA curves of ytterbium, lutetium and Yttrium 4-chlorobenzylidenepyruvates are shown in Figure 1 and Figure 2. These curves show mass losses in several steps in the 60-939 ${ }^{\circ}$ $\mathrm{C}$ temperature range. The great similarity of these curves suggest that the thermal decomposition occur in the same way.

The mass loss due to the dehydration begins at $60^{\circ} \mathrm{C}$ and it is certainly due to the air flux used $\left(100 \mathrm{~mL} \mathrm{~min}^{-1}\right)$. It occurs in one step up to $150{ }^{\circ} \mathrm{C}$. This behavior seems to be characteristic of amorphous compounds [14].

In all the TG curves the mass losses occur in three consecutives steps with formation of the oxychoride as an intermediate which has already previously observed [14]. The last mass loss is ascribed to the thermal decomposition of the intermediate compound to the respective oxide $\left(\mathrm{Ln}_{2} \mathrm{O}_{3}, \mathrm{Ln}=\mathrm{Yb}, \mathrm{Lu}, \mathrm{Y}\right)$.

The DTA curves for all the compounds show a endothermic peak due the dehydration and three exothermic peaks between 200 and 600 ${ }^{\circ} \mathrm{C}$, attributed to the thermal decomposition of the anhydrous compounds, where the oxidation of the organic matter takes place in consecutives steps; in agreement with the TG curves.

Reliable methods to determine the activation energy using dynamic integral TG curves at several heating rates have been proposed by Ozawa and Flynn and Wall. A software based on these methods was used to handle the TG data, allowing the evaluation of the apparent activation energy. A detailed mathematical procedure employed for a better software comprehension has been reported by Fernandes et al. [3,4,12,13].

Blaine [7] formulated a correlation between the Toop and the Flynn-Wall methods in software form, by which the lifetimes of different materials can be determined. The program was used for data processing with respect to the dehydration of compounds studied. $\frac{\partial \log \beta}{\partial 1 / T} \cong-\left[\frac{0.457}{R}\right] . E$

The insertion of the $\mathrm{R}$ value $8.314 \mathrm{~J} \mathrm{~mol}^{-1}$ $\mathrm{K}^{-1}$, in the equation (1) and developing it for $\mathrm{E}$, it is obtained:

$$
E \cong-4.35 \frac{\partial \log \beta}{\partial 1 / T}
$$

Thus, it is possible in this way to calculate the activation energy relating to the thermal decomposition of a compound, by using the slope of the logarithmic heating rate curve as a function of reciprocal temperature.

Toop [11] determined a relationship between the activation energy and the estimated lifetime for several materials:

$$
\ln t_{f}=\frac{E}{R \cdot T_{f}}+\ln \left[\frac{E}{\beta \cdot R} \cdot P\left[\frac{E}{R \cdot T_{c}}\right]\right]
$$

Where $t_{f}$ is the estimated lifetime, $\beta$ is the heating rate, $E$ is the activation energy, $T_{f}$ is the temperature to which the system is exposed, $\mathrm{R}$ is the gas constant and $T_{c}$ is the temperature at which the mass loss is $5 \%[=f(\beta)]$.

With the rearrangement of Eq. (3), the temperature of water removal $\mathrm{T}_{\mathrm{f}}$ can be determined for a desired process time:

$$
T_{f}=\frac{E / R}{\ln t_{f}-\ln \left[\frac{E}{\beta \cdot R} \cdot P\left[\frac{E}{R \cdot T_{c}}\right]\right]}
$$

A plot of this equation shows that a small increment in the temperature causes a drastic decrease in the time requeride for dehydration of the compounds.

A plot of the log (heating rate) versus the reciprocal temperature at constant conversion was sketched and it wa posible the calculation of E (activation energy) from the olpes of the lines obtained. The linearity observed for several conversion percentages confirms that the adopted kinetic model can be used to evaluate the dehydration of the compounds (Figure 4).

The parallel behaviour and the linearity of the curves demonstrates a kinetics of first order for the step of dehydration of the 4clorobenzylidenepyruvates of $\mathrm{Yb}, \mathrm{Lu}$ and $\mathrm{Y}$. 


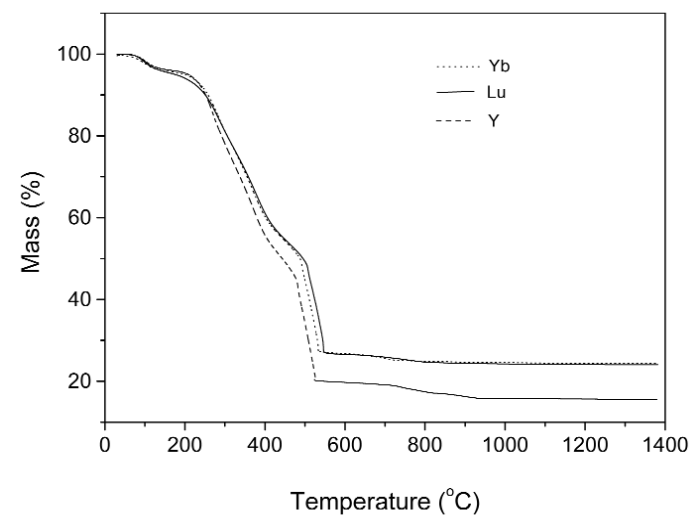

Figure 1. TG curves of the 4-chlorobenzylidenepyruvate of $\mathrm{Yb}, \mathrm{Lu}$ and $\mathrm{Y}$.

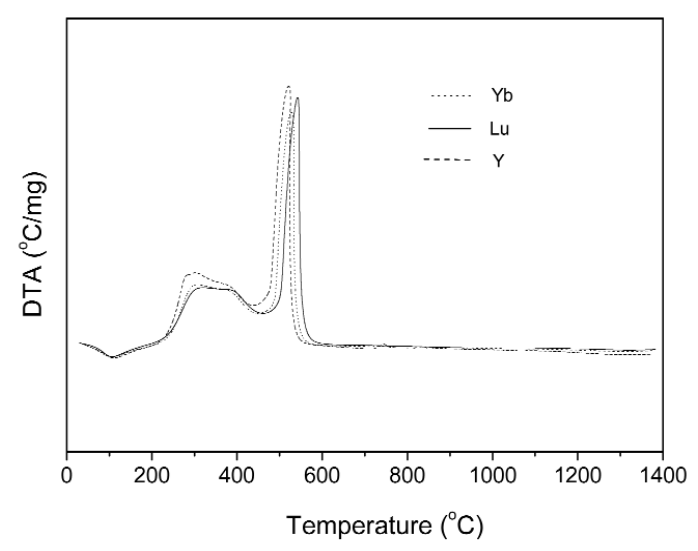

Figure 2. DTA curves of the 4-chlorobenzylidenepyruvate of $\mathrm{Yb}, \mathrm{Lu}$ and $\mathrm{Y}$.

Considering the percentege of $10 \%$ of conversion, the activation energies for the thermal dehydration of the compounds studied were 103.6; 96,7 and 97.2 KJ/mol, respectively.

From the relationship of Toop [11], it is possible to plot lifetime vs. dehydration temperature. It was observed that, to remove the hydration water considering the temperature of 31 and $101{ }^{\circ} \mathrm{C}$ the lifetime for the thermal dehydration of the compounds studied were 23, 26, 31 minutes and $0.6,1.3,1,4$ second, respectively. The results have very close values and suggest that the water is attached in the same way.
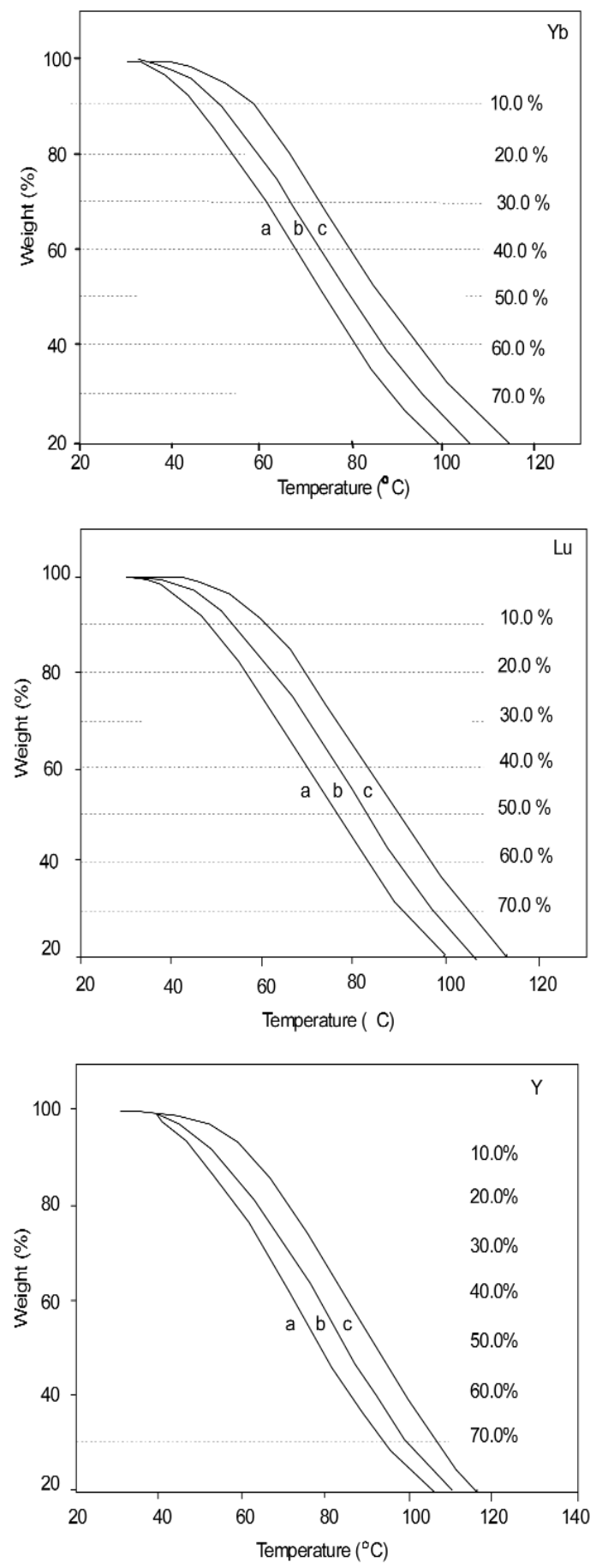

Figure 3. Multiple heating rate $(\mathrm{a}=2.5 ; \mathrm{b}=5.0$ and $\mathrm{c}=10.0^{\circ} \mathrm{C} \mathrm{min^{-1 } )} \mathrm{TG}$ integral curves for dehydration step of the chlorobenzylidenepyruvate of the $\mathrm{Yb}, \mathrm{Lu}$ and $\mathrm{Y}$. 

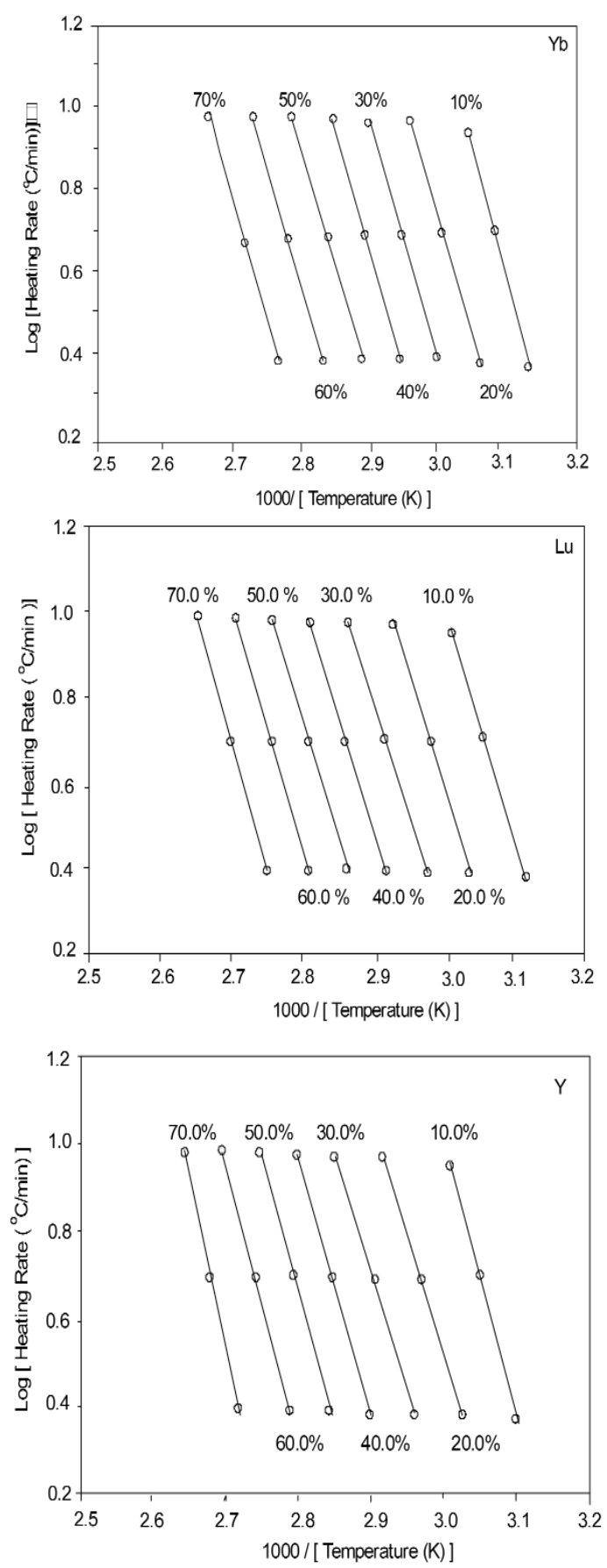

Figure 4. Logarithm of heating rate versus the reciprocal temperature for determination of activation energy of the dehydration step of the 4-chorobenzylidenepyruvate of $\mathrm{Yb}, \mathrm{Lu}$ and $\mathrm{Y}$.
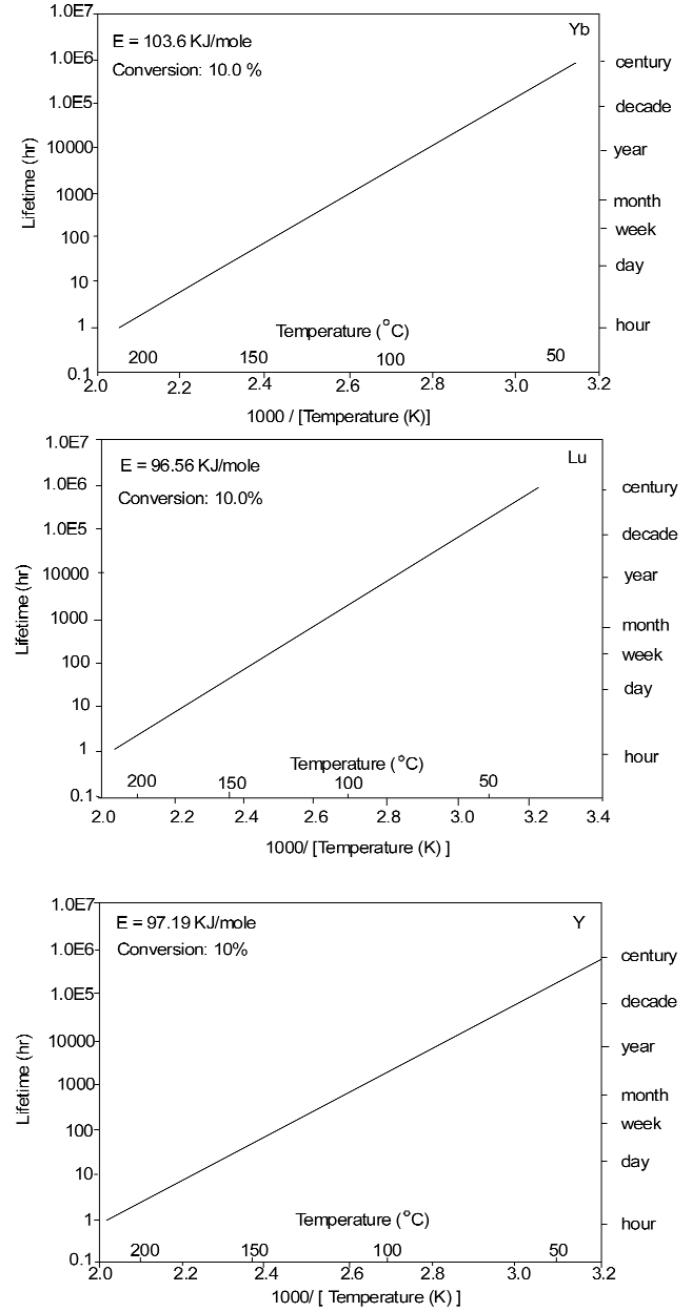

Figure 5. Dehydration lifetime of 4-chlorobenzylidenepyruvate of $\mathrm{Yb}, \mathrm{Lu}$ and $\mathrm{Y}$ vs. Temperature.

\section{Conclusions}

The results obtained showed that the kinetic model proposed suits well in the dehydration step, fact that is confimed by the linearity observed when the logarithm of several heating rate is plotted against the reciprocal temperature of water removal for several percentages of conversion.

The activation energies calculated for the step of dehydration of the compounds presented very close values, suggesting that the water is binding in the same way in the samples. 


\section{Acknowledgements}

The authors thank FAPESP (Proc.
Recebido em: 12/04/2006

Aceito em: 05/05/2006

97/01538-0) for the finantial support.

N. S. Fernandes, S. A. Araujo, M. Ionashiro. Parâmetros cinéticos de desidratação dos 4clorobenzalpiruvatos de itérbio, lutécio e ítrio por termogravimetria (TG).

Resumo: A cinética de desidratação dos 4-clorobenzalpiruvatos de itérbio, lutécio e ítrio foi estudada utilizando a Termogravimetria e os parâmetros cinéticos obtidos pelo método Flynn e Wall sugerem que a etapa de desidratação segue um mecanismo de primeira ordem. A energia de ativação (Ea) calculada foi 103,6, 96,6 e 97,2 kJ/mol e o tempo de meia-vida considerando as temperaturas de 31 e 101 oC para a desidratação térmica dos compostos estudados foram 23, 26, 31 minutos e 0,6, 1,3 e 1,4 segundos, respectivamente. Os resultados possuem valores muito próximos e sugerem que a água está ligada da mesma forma nos compostos estudados.

Palavras-chave: cinética; termogravimetria; lantanídeos; decomposição térmica.

\section{References}

[1] T. Ozawa, Bull. Chem. Soc. Jpn. 38 (1965) 1881.

[2] J. H. Flynn, L. A. Wall, Polym. Lett. 4 (1966) 323.

[3] V. J. Fernandes Jr., A. S. Araujo, Thermochim. Acta 255 (1995) 273.

[4] V. J. Fernandes Jr., A. S. Araujo, J. Thermal Anal. Cal. 56 (1999) 811.

[5] T. S. Andy Hor, L. T. Phang, Thermochim. Acta 178 (1991) 287.

[6] L. Barral, , J. Lopez, I. Lopez-Bueno, P. Nogueira, C. Ramirez, M. J. Abad, J.Thermal Anal. Cal. 55(1) (1999) 37.

[7] R. L. Blaine, Du Pont Thermal Application Brief, TA 84 (1980).
[8] L. C. S. Oliveira, C. B. Melios, M. S. Crespi, C. A. Ribeiro and M. Ionashiro, Thermochim. Acta 219 (1993) 215.

[9] M. H. Miyano, C. B. Melios, C. A. Ribeiro, H. Redigolo and M. Ionashiro, Thermochim. Acta 221 (1993) 53.

[10] C. D. Doyle, J. Appl. Polym. Sci. 6 (1992) 639.

[11] D. J. Toop, IEEE Trans. Electr. Insul. EI-6 (1) (1971) 2.

[12] V. J. Fernandes Jr., A. S. Araujo and G. J. T. Fernandes, Stud. Surf. Sci. Catal. 105 (1997) 941.

[13] V. J. Fernandes Jr., A. S. Araújo and G. J. T. Fernandes, J. Thermal Anal. Cal. 56 (1999) 1279.

[14] N. S. Fernandes, M. A. S. Carvalho Filho, C. B. Melios and M. Ionashiro, J. Thermal Anal. Cal. 73 (2003) 307. 